Ssciendo Studia Anglica Posnaniensia 56s1 (2021): 631-653

doi: 10.2478/stap-2021-0013

\title{
POLISH LGBTQ+-RELATED ANGLICISMS \\ IN A LANGUAGE CONTACT PERSPECTIVE
}

\author{
ALICJA WitALISZ ${ }^{1}$
}

\begin{abstract}
Research on anglicisms in Polish has nearly a century-long tradition, yet it was Jacek Fisiak's 1960s-1980s studies on English loanwords that initiated continuous academic interest in anglicisms, coinciding with more intensive English-Polish language contact in post-war Poland. While English loans have been well-researched in the last four decades, the ongoing intensity of English lexical influence on Polish, yielding not only new loans but also new loan types, calls for further studies, especially in the area of quickly developing professional jargons and sociolects. The influx of English-sourced lexis is reflected in the diversity of semantic fields, whose number has grown from 18 (identified in Stownik warszawski 1900-1927) to 45 (Mańczak-Wohlfeld 1995). A semantic field that has been underresearched in studies on Polish anglicisms is the LGBTQ+related lexis, which has drawn from American English gayspeak, shaped by the post-Stonewall gay rights movement initiated in the 1970s. The language data analysed in this study have been collected in a two-stage procedure, which included manual extraction of anglicisms sourced in a diversified corpus of LGBTQ+-related written texts, published in Polish between 2004 and 2020. The second stage involved oral interviews which served a verification function. The aim of this study is to contribute to the lexicographic attempts at researching English-sourced LGBTQ+-related vocabulary in Polish through its identification, excerption, and classification. Assuming an onomasiological approach to borrowing, we arrange LGBTQ+-related anglicisms on a decreasing foreignness scale to identify the borrowing techniques adopted by the recipient language speakers in the loan nativization process. We also address issues related to the identification and semantics of loans, and sketch areas of research on loan pragmatic functions that need further studies.
\end{abstract}

Keywords: LGBTQ+ discourse; sociolect; anglicism; borrowing technique; semantic field.

\section{Introduction}

English linguistic influence on Polish has been explored on both theoretical and empirical levels, and lexical anglicisms in Standard Polish have been relatively

1 Pedagogical University of Kraków; ul. Karmelicka 41, 31-128 Kraków, Poland; alicja.witalisz@up.krakow.pl 
well-researched in numerous studies, of which the first appeared in the 1930s. Coinciding with the growing intensity of English-Polish language contact in postwar Poland, Jacek Fisiak's 1961 doctoral dissertation and his later Anglicismrelated works raised continuous scholarly interest in English-sourced lexical loans. Over the last century, they not only have changed quantitatively, multiplying more than ten times, but also qualitatively, both in terms of the semantic fields they represent and the loan types that reflect different nativization techniques and vary in the degree of foreignness. The English-Polish language contact has changed as well. While it is still unidirectional, post-1989 anglicisms have been borrowed directly from English without the mediation of other languages.

Despite extensive anglicism-related studies, more recent of which exploit new theoretical approaches and methodologies, the intensity of English-Polish language contact calls for further research, especially in the area of quickly developing professional jargons, subcultures and their sociolects. One of the semantic fields that have been underresearched in studies on Polish anglicisms is the LGBTQ+-related lexis, used in reference to issues concerning Polish LGBTQ+ community.

The development of Polish LGBT sociolect has been observed since the advent of the Internet, which has provided an opportunity for a different type of communication, non-face-to-face, anonymous (Omyliński 2012). The distinctive vocabulary and specific language features typical of male homosexuals in Poland have been labelled in a number of studies as "slang gejów" ['gay slang'] (Omyliński 2012; Nowak 2017), "socjolekt gejów" ['gay sociolect'] (Dyszak 2012a; Rejter 2013: 31; Nowak 2016, 2020), “język gejów” ['gay language’] (Łydka 2019), which suggests that Polish linguistic studies have been largely male gay-oriented. More inclusive terms, including "słownictwo mniejszości seksualnych" ['lexis of sexual minorities'] (Dyszak 2015), "genderlect?" (Kita 2016: 133), and "język/slang LGBT" ['LGBT language/slang'] (Zabłocki 2019: 121), have been less common. In view of the terminological chaos and the overlapping of terms used in the sociolinguistic literature to denote a variety of language used by a particular social group (see, e.g., Grabias 1997: 141), we adopt the term "sociolect", as defined by Wilkon (2000: 88): "varieties of language related with social groups", and Grabias (1997: 11): "varieties of national language originating in various social groups", to refer to the language variety used by the LGBTQ+ community. A sociolect serves a uniting function and is used by a stable social community whose members are related through interpersonal networks and feel a strong separate identity in relation to other social groups (Wilkon 2000: 88).

For the purposes of the present study, whose major aim is the identification of LGBTQ+-related ${ }^{2}$ anglicisms in Polish, the corpus exploited for material

2 The acronym $L G B T Q+$ is used in this study as a generic and inclusive term. A discussion of the 
excerption must extend beyond 'gay sociolect' or the 'vocabulary of sexual minorities'. We will use a variety of texts that are part of LGBTQ+-related discourse, which we understand as both the language used by the LGBTQ+ speakers themselves, used, e.g., for self-identification, and the language used in reference to the LGBTQ+ community and issues by non-LGBTQ+ language speakers. More specifically, we will examine LGBTQ+-related vocabulary, understood as lexis that names LGBTQ+-related issues, behaviours, symbols, sexual practices, etc. (see Section 5.3). LGBTQ+-related discourse, used in this study as a working label and a generic concept, includes a variety of LGBTQ+related texts which will be used as sources of language data. Preliminary research points to the polycentricity of the LGBTQ+-related discourse and its subvarieties, which exhibit various degrees of formality, ranging from formal and academic texts and press articles to highly informal conversational language used in casual communication with group members. Therefore the corpus used in this study includes texts of various genres and degrees of formality. The sociolect of Polish LGBTQ+ community is by no means homogeneous and it is characterised, as evidenced in the empirical section of this paper, by features that have been identified, e.g., for Polari, such as multiple spellings or meanings (Cox \& Fay 2014; Baker 2019: 288). ${ }^{3}$

Polish LGBTQ+-related discourse borrows from English not only due to the lingua franca status of English but, primarily, due to the fact that the Gay Liberation Movement began in the United States and that English has a long history of gay sociolect, both in the USA and UK. Krzyszpien (2010: 142) argues that the Polish LGBTQ+-related discourse is influenced by texts written in English due to the leading role of American activists, academics, and artists engaged in the gay rights movement (see also Zabłocki 2019: 129). English-sourced Polish LGBTQ+-related lexis may be seen to function as an element of constructing identity (Haggerty 2013: 373) and as a way of neutral labelling taboo concepts.

The present study is meant to offer new insights into the ongoing research in the field of Polish LGBTQ+-related discourse through contributing to the exceptionally rare lexicographic attempts at researching English-sourced LGBTQ+-related vocabulary in Polish. Assuming a contact linguistics perspective and an onomasiological approach to borrowing, seen as a word-finding process, we

(in)appropriateness or (in)completeness of this abbreviation is beyond the scope of this paper. See Scheller-Boltz's (2017: 287) critical remarks on the acronym $L G B T$, which "neither reflects nor encompasses the full spectrum of queer identities", and on its extensions, e.g., $L G B T T Q Q F A G P B D S M$ (lesbian gay bisexual transsexual transgender queer questioning flexual asexual genderfuck polyamorous/pansexual bondage dominance sadism masochism).

3 " $[\mathrm{A}]$ Polari word will possess multiple spellings, meanings, origins and in some cases pronunciations, owing to the secretive, unstandardized, constantly changing nature of the lexicon" (Baker 2019: 288). 
set out to identify, analyse and describe anglicisms used in Polish LGBTQ+-related discourse. The research question is not whether English-sourced LGBTQ+-related vocabulary is used in Polish, but the size of this lexicon and the borrowing techniques adopted in the loan nativization process. Using a decreasing foreignness scale in the typology of foreign loans, which may range from overtly foreign to completely nativized, we classify the research material in respect of the degrees of foreignness, addressing both overt and covert loans, the co-existence of various loan types, and loanword adaptation techniques. We also outline problems concerning the identification of some loan types. Within this broad semantic field, we define thematically-oriented subfields. The study has purely descriptive and lexicographic aims; sociolinguistic issues lie beyond the scope of this paper.

In view of the multiplicity of sources from which research material may be excerpted (see Section 4), this paper should be seen as a preliminary study and an introduction to usage-based, genre- and sexual minority-specific research on LGBTQ+ anglicisms. Suggestions for further research are provided throughout the text.

\section{Anglicisms in Polish (with reference to semantic fields) - an overview}

To set the scene, we briefly report on the quantitative and qualitative changes in the outcomes of English-Polish language contact, and assess the degree to which English has influenced Polish using Thomason and Kaufman's 5-stage borrowing scale (1988: 74-76). The overview concerns the influence of English on Standard Polish, leaving aside anglicisms used by Polish diasporas in English-speaking countries.

The English-Polish language contact is predominantly unidirectional with intensive borrowing of mainly lexical items from (American) English, which, as observed in numerous language contact studies, has served as a lexical reservoir for many other languages worldwide. Lexical anglicisms in Standard Polish have been relatively well-researched, with the first study appearing in 1937 and presenting a body of data that included 531 anglicisms (Koneczna 1936-1937). In the 1960s and 1970s, the continuous and intensifying influx of anglicisms in post-war Poland prompted Jacek Fisiak to offer theoretical background and carry out empirical studies of English-sourced lexis, which inspired numerous other works, of which a full account or even a list cannot be compressed in a single paper (see an extensive bibliography in Witalisz 2016).

While the first anglicisms were registered in Polish already in the early $17^{\text {th }}$ century, their significant growth was registered only in the last decades of the $20^{\text {th }}$ century (Mańczak-Wohlfeld 2010). Currently, anglicisms (of various types) in Standard Polish amount to, according to various counts, between 5,500 and 8,000 
items, which, if we take the higher number into consideration, constitutes ca. $3.6 \%$ of the Polish lexicon (Fisiak p.c. $;^{4}$ Witalisz 2016: 168-169). Studies on anglicisms in selected Polish professional jargons (IT, corporations, medicine, law; in Zabawa 2017; Cierpich 2019; Górnicz 2019, respectively), suggest a higher ratio. Hardly significant in terms of numbers, anglicisms are marked by a high frequency of use, which stems from their onomasiological and expressive functions, cf., e.g., Pol. smartfon (< Eng. smartphone), Pol. mail (< Eng. e-mail), Pol. laptop, Pol. internet (< Eng. Internet), okej (< Eng. OK), sorry/sory. ${ }^{5}$

Polish $20^{\text {th }}$-century anglicisms were predominantly lexical (loanwords), as evidenced in Fisiak's (e.g., 1961, 1970) and Mańczak-Wohlfeld's (1992, 1995, 2010) studies. The political and social changes of 1989 encouraged Poles to draw freely from English, and the unprecedented influx of anglicisms that followed resulted in exploiting other borrowing techniques, such as loan translating, semantic borrowing, loanblending (see, e.g., Otwinowska-Kasztelaniec 2000; Zabawa 2012, 2017; Witalisz 2007, 2015, 2016; only to mention monographs). The outcomes of English-Polish language contact in the areas of lexis, phonology, and grammar observed thus far suggest that English influence on Polish has reached the middle stage, "more intense contact", on the 5-stage borrowing scale proposed in Thomason and Kaufman (1988: 74-76). Poles borrow both basic and non-basic vocabulary, introduce minor contact-induced structural loans, and, at the morphological level, abstract derivational affixes and combining forms from polymorphemic loanwords to recycle them creatively in native word-formation. At the phonological level, borrowing is confined to the adoption of new phonemes that are part of loanwords (see exemplification in, e.g., Witalisz 2016: 141). Poles' willingness to adopt English material may undoubtedly be attributed to the lingua franca status of English, the cultural dominance of the USA, and also to the growing English-Polish bilingualism of Polish speakers that results from the foreign language teaching policy.

The growing intensity of the English influence on Polish is reflected in the distribution of lexical anglicisms in semantic fields, ${ }^{6}$ whose diversity is evidenced by their number that has grown from 18, identified in Stownik warszawski (19001927; Mańczak-Wohlfeld 1988a), 23 fields in Koneczna (1936-1937), and 12

4 Personal communication with Prof. Jacek Fisiak. The number of lexical anglicisms collected by his team was estimated at ca. 7,000 items (August 2016).

5 English etymons are provided only if the loanword differs graphically and/or morphologically from its etymon.

$6 \quad$ We adopt the term "semantic field" after Mańczak-Wohlfeld (1995: 68) for the typology of loanwords into semantically related groups (cf. Koneczna's "kategoria znaczeniowa" ['semantic category'] (1936-1937: 163) and Fisiak's "field of life" (1970: 41)). We abandon the detailed distinctions between, e.g., lexical field and semantic field, as explicated in Miodunka (1980: 54). 
main and several dozen minor subfields presented in Fisiak's 1970 study, to 42 and 45 semantic fields listed in Mańczak-Wohlfeld (1988b, 1992 and 1995, respectively). ${ }^{7}$ The 1988 and 1992 accounts for the first time include the fields of computers, meteorology, and cybernetics, while the 1995 list registers additionally the semantic areas of advertising and drugs, with the latter poorly represented at the time. All pre-2000 studies point to sports (and games) as the most richly represented semantic field, followed by maritime terminology, science, technology, cultural life, and society. Semantic studies carried out for English semantic loans and loan translations point to politics, business, economics, banking, trade, journalism, computers, and popular culture as the most richly represented semantic fields in the area of covert loans (Witalisz 2007, 2015). Over the decades of the English linguistic influence on Polish, we have witnessed a change in the proportion of anglicisms in various semantic fields, which is directly related to the changing world and human behaviour (see, e.g., Zabawa's 2017 account of IT anglicisms).

A semantic field that is missing from the semantic analyses of Polish anglicisms is the sociolect of Polish LGBTQ+ community, or more generally, the LGBTQ+-related discourse (single instances found in SZA and Witalisz 2015). Lack of reference to LGBTQ+-related anglicisms in previous Polish language contact studies is hardly surprising in view of the fact that English-sourced LGBTQ+-related lexis started to appear in Polish only in the 1990s, as stems from various sources referred to later in the paper.

\section{Anglicisms-related research on LGBTQ+ sociolect}

We begin a synopsis of anglicisms-related studies on LGBTQ+ sociolect with reference to a popular feature article by Omyliński (2012), published in an online portal "Na Temat", which was a stimulus for the present research in LGBTQ+ anglicisms. The author lists and defines 30 gay sociolect words, of which half have been identified by the present author as sourced in English. The title itself, "Kod seks-czatów i slang gejów. Tajemny język branży" ('The code of sex chats and gay slang. The secret language of [lit.] branch [i.e., "LGBTQ+ community']'), includes five English loanwords.

The sociolect of Polish gays, with special focus on lexis, is addressed in a series of research articles by Dyszak, who examines gay-related vocabulary used by the characters of a well-known gay novel Lubiewo (Witkowski 2014), and contrasts it with the contents and semantic explications found in selected dictionaries of Polish

While examining the number of semantic fields listed in each study, we noted that each researcher used somewhat different labelling and divergent degrees of specificity; therefore the quantitative data should be treated as a rough guide. 
(Dyszak 2012a). The author analyses the names of sexual practices, names of people, their attributes and behaviours, as well as names of places, male organs, and sexually stimulating agents, and argues that many of them constitute synonymous sets. The research is continued in Dyszak (2012b), which is a critical comparative overview of dictionary entries defining male gay people in Polish general, colloquial, slang, and argot dictionaries. The most interesting, from the perspective of the present study, is Dyszak's 2015 work (and its 2016 English translation), in which the author attempts at collecting sociolectal vocabulary used by Polish sexual minorities. Most of the 90 collected words, sourced in amateur mini-dictionaries available online, private blogs, and feature articles, are analysed as native semantic and word-formation neologisms (Dyszak 2015: 209). Foreign loans are argued to be infrequent, amounting to 19 items, all loanwords of English origin. Worth noting is the distinction Dyszak makes between loanwords borrowed from English-language gay slang, e.g., Pol. bear, coming out, darkroom, and from Standard English, e.g., Pol. soksy (< Eng. socks), gay-friendly, kesz (< Eng. cash) (2015: 213-214). We argue that some of the phraseological units labelled as neologisms, are, in fact, sourced in English and have been borrowed as loan translations, e.g., Pol. tęczowa flaga (< Eng. rainbow flag).

Polish gay sociolect is also analysed in Nowak (2016), which is an overview of words denoting names of meeting places for male homosexuals. The examples were excerpted from Polish 1980s and 1990s gay zines and include, e.g., Pol. Broadway, used in Polish in a specific gay-related sense. A detailed comparative study of two Polish slang words denoting male gays is offered in Nowak (2017, and its 2018 English translation). Pol. ciota (lit. 'auntie') and Pol. ciepty (lit. 'warm') are compared in a cross-linguistic analysis with their equivalents in seven European languages. The author notices user- and context-dependent polysemy of gay sociolect vocabulary and some degree of lexical uniformity among gays representing different linguistic backgrounds (Nowak 2017: 253). In a 2019 paper, Nowak "decodes [...] the language of concealment" ("język ukrycia"), i.e., the language of Polish male gays ("pedałów i ciot" [Pol. pedat < most probably from Fr. pédé(raste); Pol. ciota, lit. 'auntie') used between the 1950s and 1990s (Nowak 2019: 196). Though beyond the author's intention, the study indirectly points to the lack of English-sourced loanwords in Polish gay sociolect of the second half of the $20^{\text {th }}$ century, excluding its last decade. This can also be inferred from Nowak (2020), in which we find a corpus-based collection of pre-2002 gay sociolect vocabulary classified into 20 semantic subfields. It is not clear why the subfield labelled "borrowed names" ('nazwy zapożyczone', 2020: 254), including 3 English loanwords, fisting, jack-off, and spanking, excludes other English-sourced words listed in the other subfields, e.g., gej, darkroom, coming out. Altogether, Nowak's 2020 material includes 16 Englishsourced expressions listed under various semantic fields. 
In a study on "coming out", seen as a new genre in Polish public discourse, Kita argues that despite the easily observable English linguistic influence on the sociolect of the Polish LGBT community, we still lack a comprehensive or even partial study of LGBT anglicisms in Polish (Kita 2016: 137). The author observes that the word coming out has been borrowed into Polish together with many other lexical items typical of the LGBT discourse and briefly comments on the adaptation techniques used in the case of the English-sourced coming out. While it retains its original graphic form and close-to-original pronunciation, it surrenders to inflection and exhibits word-formation productivity. Coming out has also been "polonized" and has several loan translated versions, some of which are free renderings of the English model: wyjście z szafy, wyjście z klozetu, wyjście z toalety, wyjście z ukrycia, przejście na druga stronę lustra, ujawnienie (Kita 2016: 137).

A translator-oriented perspective is adopted in a study by Zabłocki (2019), which is a commentary on English-sourced gay words in Polish and some other languages. The author states that quite a few expressions used by the Polish LGBTQ+ community have been borrowed from English, either in the form of direct translations or adapted loanwords that have been nativized to match Polish inflectional and syntactic paradigms. This is a phenomenon present also in other languages, as exemplified by gay, camp and queer, a classic triad ("kanoniczna triada") that, in the author's view, illustrates the fact that English is unquestionably the "dominant language" in the LGBTQ+ context (Zabłocki 2019: 121, 126). Other English-sourced words mentioned in the text include, e.g., drag queen, coming out and its loan translated variant wyjście z szafy, outing, bareback, cross-dressing, darkroom, twink, gaydar.

Since Polish is not the only language heavily influenced by English, for reasons of a (provisional) cross-linguistic comparison, we also refer to a handful of studies on LGBTQ+ sociolect used by speakers of other languages. Assuming a diachronic perspective, Rodríguez González (2008a) scrutinizes anglicisms used by Spanish male homosexuals and in reference to male homosexuality. Most analyzed anglicisms are recent, though the first appeared already in late $19^{\text {th }}$-century Spanish (2008a: 248). Similarly to other researchers, Rodríguez González emphasizes the semantic inconsistency in some key terms, e.g., camp (2008a: 250). The author notes that the neutral English-sourced gay replaced the negative Spanish marica and maricón, which finds an analogy in the Polish context, in which the nonoffensive gay replaced ciota (lit. 'auntie') and pedat (< Fr. pédé(raste)), both considered offensive if used by non-gay people. The two Spanish terms are argued not to evoke negative connotations if used by gay speakers, which, again, is analogical to the Polish context. This, in a way, parallels the history of the word queer, which was used with negative overtones in American English since the 1920 s, when it adopted the meaning 'homosexual', to be later reappropriated by gay activists as a positive denotation of gay people in the 1980s (see, e.g., Curzan 
2014: 152; AHD). ${ }^{8}$ The article also discusses the word-formation productivity of the word gay in Spanish, which finds parallels in Poles' derivational creativity (cf. Nowak 2020: 117). In a 2017 study based on Diccionario gay-lésbico (2008b) and Nuevo diccionario de anglicismos (1997), Crespo-Fernández \& Luján-García (2017) examine the axiological values of 250 Spanish homosexual anglicisms of various types. The authors found lexical loans (including clippings and acronyms) and pseudo-anglicisms to be the most frequent types of anglicisms, with covert loans, hybrids, and adapted loans being less common. Both Spanish collections encourage cross-linguistic research on LGBTQ+ anglicisms

Examining a corpus of texts taken from gay press, Provencher (2007) analyses the ways sexuality is expressed in current French and argues that the French LGBT community draw lexically, though with reservations, from American English to express concepts such as gay pride, coming out, and AIDS education. Divita \& Curtis (2019) focus on the diachronic use of a single LGBTQ+-related Anglicism, le coming out, and offer a corpus-based analysis of its formal variance that includes the French le come-out. The authors emphasize the gradual change in the types of context in which the loanword has been found in French over a period of two decades, from referring exclusively to foreign reality to describing local coming outs.

Preliminary cross-linguistic studies suggest that the same LGBTQ+-related anglicisms are found in Spanish (Rodríguez González 2008a), French, ${ }^{9}$ and Polish, e.g., bear, butch, cisgender, coming out, daddy, gay, LGBT, to be outed, also in their loan translated or loanblended variants, e.g., gay rights $>$ Sp. derechos de los homosexuales, Fr. les droits des homosexuels, Pol. prawa gejów, and as semantic loans, e.g., active, passive > Sp. activo, pasivo, Fr. actif, passif, Pol. aktywny, pasywny. These anglicisms, shared by several European languages, have been drawn from the American tradition of post-Stonewall gay identity politics and gay rights movement (cf., e.g., Leap \& Boellstorff (2004), who write on gay language and globalization; Provencher (2007: 2), who uses the term "global (gay) English").

\section{Corpus and method of data excerption}

The language data used in this study are sourced in a variety of LGBTQ+-related publications. For lack of readily available tools for automatic loan identification, data excerption has been carried out manually. Despite promising attempts in the field of corpus linguistics, anglicisms retrieval, including semi-automatic searches

\footnotetext{
8 We leave aside addressing the semantic inconsistency and various understandings of the term queer, which has received much attention in numerous studies.

9 See, e.g., https://www.frenchtoday.com/blog/french-vocabulary/french-lgbtq-vocabulary/; https://www.talkinfrench.com/french-gay-slang.
} 
for pre-identified features, is still dependent on the researcher's knowledge and experience. While overt loans are relatively easily identifiable given their formal attire, the identification of covert foreign loans and confirmation of their loan status require diachronic dictionary- and corpus-based research.

Preliminary research on anglicisms used in Polish LGBTQ+-related discourse has led to an observation that English-sourced vocabulary is used both by the LGBTQ+ community, for purposes of naming and self-identification, and by others to refer to LGBTQ+-related matters. LGBTQ+-related anglicisms vary in the degree of formality and thus must be searched for in various text types. In an attempt to collect, in this general preliminary study, a sizeable body of data, the sources used for material excerption vary in the degree of formality and represent different genres; they were published in the years 2004-2020 and include the following types of LGBTQ+-related texts (for details see References):

- $\quad$ academic works and general publications (10),

- $\quad$ electronic press articles (2), ${ }^{10}$

- $\quad$ websites and online portals (9),

- $\quad$ online and printed amateur mini-glossaries (5),

- publicly available Facebook and Twitter accounts (7),

- gay literature (1),

- publicly available blogs (4),

- gay chats (1).

The set of publications and posts used as sources of authentic language data constitutes a diversified corpus. Frequency counting was not our goal at this point of analysis, therefore the exact size of the corpus has not been evaluated in terms of the number of words or tokens. The Polish LGBTQ+-related written output that has been published either in print or online has turned out to be limitless. The intention behind the selection of data sources was to refer to a variety of text types, which would provide authentic language material that is not limited to genre or formality level. At the same time, we realise that the list of LGBTQ+related anglicisms presented in this study is not exhaustive.

The data collected from Polish sources were verified for their potential English etymons against four dictionaries and amateur lexicographic collections of English-language LGBTQ+ sociolect, i.e.,:

10 Analysing Polish gay magazines issued in the 1980s and 1990s (e.g., Etap, Filo/Facet (19862001), Inaczej (1990-2002)) would allow the identification of the first anglicisms used by Polish homosexuals (cf. Nowak 2020). 
- Fantabulosa: A Dictionary of Polari and Gay Slang (Baker 2002),

- GLTB slang dictionary, http://andrejkoymasky.com/lou/dic/dic00.html,

- Queer undefined, a crowdsourced lgbtq+ dictionary, https://www.queerundefined.com,

- Pink News, https://www.pinknews.co.uk/2017/11/27/the-ultimatelgbt-glossary-all-your-questions-answered.

Manual excerption of language data was followed by (online) oral interviews, which served to verify the draft version of the research material. Initially, four Polish LGBTQ+ informants were asked to confirm either their active usage or passive knowledge of the English-sourced items found in the corpus. This was done to minimise the risk of including idiolectal uses in the material. In the case of ten controversial lexemes (AC/DC, broodway, cottage, cottaging, cunt, curry queen, fag hag, friend of Dorothy, rise queen, tea-room), 10 other informants representing different sexual orientations ( 3 lesbians, 1 bisexual, 6 gays) have been interviewed to guarantee material verification credibility.

The focus of this research is the identification and excerption of Polish LGBTQ+related anglicisms, their analysis in terms of the borrowing technique adopted by Polish users, and classification into loan types. Studying other aspects of the collected language data, such as their frequencies or pragmatic functions, requires building a quantitatively limited, genre-specific corpus and a close examination of single uses of particular anglicisms, which has to be left for future studies.

\section{Types of Polish LGBTQ+-related anglicisms: Findings and discussion}

The body of language data collected for this study amounts to 234 Englishsourced loans, excluding derivatives and formal variants (see Appendix), which may be analysed from various perspectives. In this study, we analyse the borrowing techniques used in the nativization of loans and classify them into loan types that reflect different degrees of foreignness. The semantic diversity of the collected data allowed their thematic subdivision. We also outline other areas of LGBTQ+ anglicism research in need of further in-depth usage-based studies.

\subsection{Etymological issues in the study of anglicisms}

In this study, we take into account the historical source of a loan, e.g., Pol. gej/gay 'a homosexual person' (< Eng. gay), Pol. femka 'passive and more feminine partner in a lesbian couple' (< Eng. fem/femme), Pol. queer [variously interpreted] (< Eng. queer), rather than the etymological source, cf. e.g., Eng. gay 'joyful, happy; pleasant, agreeably charming' (< Old French gai), Eng. fem/femme 
'woman' ( $<$ Fr. femme), Eng. queer 'oblique, off-center' $(<$ from Scottish, perhaps from Low German, Brunswick dialect, related to German quer 'oblique, perverse, odd') (ED).

One of the major problems in studying anglicisms is the confirmation of the loan status of semantic loans, which must be differentiated from native semantic developments, a task that is not always possible. The examples listed in the Appendix under the heading English-sourced semantic loans have been tested against their potential English etymons, in which context of use was of primary importance. Yet, in many cases, it does not seem possible to rule out a simultaneous process of the native semantic development of LGBTQ+-related senses, as in Pol. tata (Eng. daddy), maż (Eng. husband), żona (Eng. wife), golenie (Eng. shaving), trójkąt (Eng. threesome), which refer to certain types of people and activity within the homosexual community, and the semantic extensions are readily predictable and may be coincidental in the two languages. Instances of such semantic extensions have been excluded from the research material, similarly to single occurrences of lexemes which might or might not be interpreted as inspired by English, e.g., Pol. wesolek 'male homosexual', lit. 'a jolly man' (possibly sourced in English gay 'joyful'). Excluded from the material are also words which most probably have been borrowed from languages other than English, e.g., Pol. ciepty (brat) 'warm (brother)' < probably from Ger. Warmer Bruder (cf. Rodzoch-Malek (2012: 151), who derives Pol. ciepty/cieplak from Eng. warm brother; see also Dyszak 2012b: 71 on the German provenance of Pol. ciepty).

Finally, excluded from the material are two types of compound words: a) formations composed of classical (Greek or Latin) combining forms, and b) combinations of classical combining forms and French or English morphemes. Their etymology and historical sources are uncertain and hard to establish univocally, as in, e.g., Pol. bifobia, demiseksualny, heterocentryzm, homoerotyczny, metroseksualny, transfobia, etc. (cf. WSWO).

\subsection{Types of Polish LGBTQ+-related anglicisms}

The formal heterogeneity of the collected material, reflected in the varying degrees of loan foreignness, allows its classification into several loan types. Following the classic typology of lexical loans (Haugen 1950) and its more recent extended versions, the English-sourced expressions found in the Polish LGBTQ+-related discourse have been arranged on a decreasing foreignness scale, from overtly foreign to completely nativized, to present the nativization techniques adopted by the recipient language speakers.

Loanwords (lexical loans), e.g., Pol. bears (< Eng. bear), bareback, buczka ( $<$ Eng. butch), chemsex, coming out, darkroom, femka ( $<$ Eng. femlfemme), gej (< Eng. gay), queer, soksy (< Eng. socks), and twink, constitute the most 
numerous group of 119 items (excluding formal variants and derivatives). They include 19 English-sourced initialisms, e.g., Pol. FFS (Facial Feminism Surgery), FTM/F2M (female to male), GRS (Gender Reassignment Surgery), $H I V$ (human immunodeficiency virus), MSM (man searching man), 2 blends: chemsex 'chemicals + sex', gaydar/gejdar 'gay + radar', and 49 compound words and phraseological units, e.g., bareback, gay-friendly, glory hole, sneaker party. Formally unadapted loanwords exhibit a high degree of foreignness; yet, lack of formal adaptation, as in Pol. cishet, daddy, dyke, queen, may prove a temporary feature. $65 \%$ of the loanwords undergo formal adaptation at the morphological and/or graphic level, as evidenced by most of the examples quoted above, which is in line with the behaviour of lexical anglicisms attested in Standard Polish. The analysed anglicisms exhibit derivational potential, as in, e.g., Pol. closet $>$ sklozetowany [past. part.], Pol. cybersex > cyberek [dem. n.], Pol. gej > gejowy [n.], gejuch [augm. derog. n.], gejowski [adj.], Pol. kamp > kampowy [adj.], kampować [v.], Pol. queer > ktirowy [adj.], ktirować [v.], queerowość [abstr. n.] (see also, e.g., Nowak 2020: 117).

English-sourced loanblends, i.e., half-translations of English etymons, exhibit a lesser degree of foreignness than loanwords, e.g., Pol. cisnormatywny (< Eng. cisnormative), duma LGBT (< Eng. LGBT pride), HIV pozytywny (< Eng. HIVpositive), Kino queer (< Eng. Queer cinema), kultura drag queen $(<$ Eng. drag queen culture), stres mniejszościowy ( $<$ Eng. minority stress), tożsamość seksualna ( $<$ Eng. sexual identity). Each of the 31 loanblends identified in the material is an English-Polish polymorphemic hybrid with a discoverable English etymon. 12 loanblends follow an English word-formation rule, as in drag artysta (< Eng. drag artist), HIV pozytywny (< Eng. HIV-positive), gej randka (< Eng. gay date).

Complete morphemic substitutions of one- and multi-word foreign models exhibit maximal nativization, which is attributed to the native (or wellassimilated) material the loan translated expressions are composed of. 48 of the loan translations found in the research material are exact word-for-word translations of polymorphemic English etymons, e.g., Pol. dziura chwaty (< Eng. glory hole), język lawendowy (< Eng. lavender language), plynność ptciowa (< Eng. gender fluidity), wychodzić z szafy ( $<$ Eng. to come out of the closet), różowe pieniadze (< Eng. pink money), tęczowa rodzina $(<$ Eng. rainbow family). The first four examples exhibit formal deviation from the foreign model, which reflects the different word-formation rules for compound coining in English and Polish. Within the loan translated expressions, we found 7 loan renditions, i.e., inexact loan translations, that exhibit lexical deviation from the foreign model, as in e.g., Pol. Parada/Marsz Równości, lit. 'parade/march of equality' (< Eng. Pride Parade/Event/Festival), skórzak (skóra 'leather' + der. suffix -ak) (< Eng. leatherman), kod flagowy, lit. 'flag code' ( $<$ Eng. hanky code), polowanie na robala 'bug hunting' ( $<$ Eng. bug-chasing). 
In 11 cases, the distinction between loanblends and loan translations appears problematic and depends on the researcher's arbitrary decision concerning the formal interpretation of adjectives such as Pol. genderowy (gender + suff. -owy), gejowski (gej 'gay' + suff. -ski), dragowy (drag + suff. -owy). If used in isolation, genderowy may be interpreted as either a native adjectival derivative from the well-established loanword gender (n.), or as a morphological adaptation of the attributive gender in Eng. gender studies. In the first case, studia genderowe, the Polish rendering of Eng. gender studies, falls within the category of loan translations, in the latter, it is a case of a loanblend (Witalisz 2015: 185). In this study, we assume that loan-based adjectives, such as genderowy, are native derivatives. Yet, since the borderline between loanblends and loan translations is often fluid and the inexactness of translation in the case of loan renditions is variously understood, the three loan types have been listed together in the Appendix and amount to 86 items.

One more loan category that exhibits a minimal degree of foreignness are semantic loans, which result from the adoption of foreign meanings by native lexemes that copy the polysemy of foreign models. We have identified 29 semantic loans in the analysed corpus, cf. the LGBTQ+-related uses of e.g., Pol. aktywny/aktyw/a 'the active partner in anal sex' (< Eng. active), as 'an asexual person' ( $<$ Eng. ace), ciemnia 'a darkened room in a gay club where sexual activity takes place' ( $<$ Eng. darkroom), czajniczek 'a gay man with one hand on the hip and the other held at shoulder height' (< Eng. teapot), niebinarny 'a person who does not identify as exclusively male or female' (< Eng. nonbinary), misiek/niedźwiedź 'a gay man with specific traits, e.g., a hairy body, large built' (< Eng. bear), robal 'AIDS; HIV' (< Eng. bug), szafa 'the status of a homosexual who is yet to declare their sexuality' ( $<$ Eng. closet).

The gradual nativization process of English-sourced expressions is also evidenced by the co-existence of various loan types. For instance, loanwords are used alongside semantic loans, as in e.g., Pol. bears and misiek/niedźwiedź, Pol. ally and sojusznik, Pol. darkroom and ciemnia, Pol. queer and odmieniec. LGBTQ+-related loanwords have their loan translated or loanblended equivalents, as in e.g., Pol. coming out and wyjście z szafy, Pol. drag show and drag przedstawienie, Pol. queer studies and studia queerowe, Pol. grey-a and szara aseksualnośćlszara-A. The simultaneous usage of overt and covert loans, i.e., loanwords and their translated or half-translated variants that exhibit a lower degree of foreignness, may be interpreted either as a result of the gradual and ongoing loan nativization and institutionalization processes, or a as result of conscious lexical choices made by individual recipient language speakers, designed to evoke intended pragmatic effects. Resolving this doubt requires a usage-based approach, which necessitates detailed analyses of authentic contexts of use for each co-existing set. 
Finally, it is interesting to note that the borrowing of a number of compound loanwords that share a common morpheme leads to their morphological analysis by the recipient language speakers. The combining form, affix, or free morpheme that reappears in a number of compound loanwords is abstracted and may be recycled creatively in the recipient language. An example found in the analysed language data is the morpheme cis-, $^{-}$borrowed as part of clipped compounds and compound loanwords, e.g., Pol. cishet ( $<$ Eng. cishet [cisgender heterosexual]), cisgender (< Eng. cisgender), and loanblends, e.g., Pol. ciskobieta (< Eng. ciswoman < cisgender woman), cismężczyzna (< Eng. cisman < cisgender man). Cis- has a potential to be used creatively in independent native formations, similarly to English-sourced -ing, $e$ - and -gate used in Standard Polish.

\subsection{Semantic analysis of LGBTQ+-related anglicisms}

Several general observations can be made concerning the semantics of Polish LGBTQ+ anglicisms. Although the English-sourced loans compiled in this research can all be placed under a single umbrella term "LGBTQ+-related anglicisms", their semantic diversity lets us propose a set of LGBTQ+-related semantic subfields, which include the following:

- $\quad$ names of people, e.g., Pol. ally, buczka (< Eng. butch), daddy, drag king, drag queen, fag hag, friend of Dorothy, skate (< Eng. skater), twink,

- $\quad$ names of places and events, e.g., Pol. darkroom, cruising bar, drag show, underwear party, naked party, klub misiów (< Eng. bear club),

- names of sexual practices, activities, and behaviours, e.g., Pol. bareback, bug chasing, chemsex, (sex)czat (< Eng. sex chat), cyberseks/cyberek (< Eng. cybersex), spanking, wyautowany $(<$ Eng. outed),

- names denoting types of sexuality and sexual orientation, e.g., Pol. cisgender, transgender, queer, tożsamość gejowska (< Eng. gay identity),

- $\quad$ names of symbols, e.g., Pol. flaga tęczowa (< Eng. rainbow flag), jednorożec ( $<$ Eng. unicorn), fiotki $(<$ Eng. violet),

- names of male organs and sexually stimulating agents, e.g., Pol. boner, cock ring, soksy ( $<$ Eng. socks),

- $\quad$ medical terms, e.g., Pol. AIDS, FFS, GRS, HIV, terapia konwersyjna ( $<$ Eng. conversion therapy),

- $\quad$ scientific and legal terms, e.g., Pol. gender studies, queer studies, płeć prawna (< Eng. legal gender), językoznawstwo lawendowe (< Eng. lavender linguistics). 
The examined LGBTQ+ anglicisms are semantically convergent to their English etymons, with single exceptions of loanwords that deviate semantically from the English models. Apart from the original English meaning 'publicly disclosing an LGBT person's sexual orientation without that person's consent' (FD), Pol. outing and wyautowany (< Eng. outing, to out somebody) are also used in Polish in the sense of coming out 'openly declaring and accepting one's sexuality'. A similar observation has been made for the usage of outing in Spanish (Rodríguez González 2008a: 263), which may lead contact linguists to classify the non-English sense of outing as a pseudo-anglicism.

As attested by Polish dictionary entries, theoretical works, and corpus data, single LGBTQ+-related anglicisms, similarly to their etymons, have received various semantic interpretations and have been used with divergent meanings, which is best illustrated by the word queer, whose American English etymon has a complex semantic history (AHD; Baker 2002: 183). Pol. queer has been interpreted differently by various authors (cf., e.g., Rodzoch-Malek 2012: 156; Bieńko 2019: 88; Zabłocki 2019: 124, 125), with the most common interpretation referring to 'individuals who avoid defining their sexuality in terms of a binary system'. Non-uniform interpretations of other LGBTQ+-related terms are also discussed in Dyszak (2015) and Nowak (2016, 2017, 2019, 2020).

It is interesting to note that anglicisms such as $g e j$ are used to rename concepts that have already been lexicalized in Polish. These may be conscious pragmatic choices aimed at changing some heteronormative people's negative attitudes towards the LGBTQ+ community. Polish designations for male homosexuals, ciota and pedat, offensive and evoking negative overtones when used by nonhomosexual people, have been replaced in the politically correct public discourse with English-sourced gej (< Eng. gay). Some of these lexical replacements result in semantic extensions of native vocabulary, as in the case of Pol. ciemnia 'a room in a gay club designated for sex' ( $<$ Eng. darkroom), which replaced Pol. pikieta 'a meeting place for male homosexuals in the park or public toilet'.

Finally, we would like to make some general observations concerning the LGBTQ+-related discourse formality, register, and the idiolectal usage of anglicisms, with the reservation that register differences observed within the LGBTQ+-related discourse require further corpus-based, register-specific research. The anglicisms presented in this study have been found to appear not only in informal slang used by members of the LGBTQ+ community in informal situations, but also in the LGBT emancipation discourse. Also, they can be split into those used exclusively by members of the LGBTQ+ community for selfidentification and denotation of other group members, e.g., Pol. daddy, drag queen, fag hag, femka, pasywny/pasyw/p (< Eng. passive), sniker (< Eng. sneaker), skate (< Eng. skater), and those that are used also by the heteronormative society in reference to members of the LGBTQ+ community, 
e.g., Pol. gej, społeczność gejowska (< Eng. gay community). English-sourced expressions (either borrowed directly or loan translated/blended) allow denotation of concepts that used to be unnamed (or unknown), e.g., Pol. cisseksizm (< Eng. cissexism), społeczność LGBT (< Eng. LGBT community), prawa gejowskie ( $<$ Eng. gay rights), and acquainting the public with LGBTQ+ symbols and culture. LGBTQ+-related anglicisms are used in Standard Polish as neutral denotations of people and concepts, e.g., Pol. gej (< Eng. gay), LGBT, mniejszość seksualna (< Eng. sexual minority), but also as taboo terms, e.g., Pol. bug chasing, blowjob, cock, felching, that have been found exclusively on blogs and in informal online exchanges.

Some of the anglicisms listed in the Appendix may be typical of a particular sexual minority or even of a particular group within this minority, a confirmation of which requires further research. 16 out of 119 loanwords have been marked by the informants as rare or niche, e.g., Pol. truscum, uncut, TERF. The informants disagreed about the usage in Polish LGBTQ+-related discourse of single instances of anglicisms found in the corpus, e.g., bottom 'the passive partner in anal sex'. This may be evidence of the idiolectal usage of English-sourced lexis by individual community members and suggest that the language variety used by the LGBTQ+ community is a collection of idiolects rather than a unified sociolect shared by all its members.

\section{Conclusions}

English-sourced vocabulary is an integral part of Polish LGBTQ+-related discourse, both formal and informal. LGBTQ+-related anglicisms constitute a divergent set. They exhibit different degrees of foreignness and reflect various adaptation techniques adopted by the recipient language users in the namefinding process. We have shown that an English etymon may be rendered in a number of ways by Polish speakers, leading to the co-existence of various loan types. This is part of a gradual nativization and integration procedure, typical of the borrowing process, but may also be a result of individual speakers' conscious lexical choices aimed at evoking desired pragmatic effects. It is unsurprising that more formal LGBTQ+-related anglicisms appear in general public discourse and are comprehensible to an average educated Pole. By contrast, informal and taboo LGBTQ+-related anglicisms are reserved for the LGBTQ+ community, as their distribution is limited to LGBTQ+-related blogs and chats.

Polish LGBTQ+ Anglicisms are relatively recent, as indicated in Section 3 and inferred from the narrator's words in Lubiewo (Witkowski 2014), who notes that gej (< Eng. gay) has replaced native ciota and pedat, not only in the lexicon but also in the societal consciousness (cf. also Nowak 2020). Assessing the 
(non-) catachrestic character (Onysko \& Winter-Froemel 2011) of LGBTQ+related anglicisms requires not only identifying their potential native semantic equivalents but also examining their pragmatic functions. Finding out whether Pol. pedat is a semantic equivalent of English-sourced gej is likely to yield equivocal results that are speaker-, hearer-, context-, and sociolect-dependent. The use of anglicisms that have their native equivalents can be seen as a conscious, pragmatically marked lexical choice of the recipient language speaker.

In several cases, the meanings of LGBTQ+-related anglicisms have been hard to define due to their varied interpretations and usage in the corpus. As confirmed by the informants and attested by contexts of use, individual understanding of LGBTQ+ vocabulary depends on and reflects the degree of emancipation and self-consciousness of individual speakers, who may, additionally, exhibit various emotional attitudes to the vocabulary used. As sociolect lexis is prone to changes, semantically controversial anglicisms should be studied in detail from a usagebased perspective (Backus 2014), in which the usage and semantics of a single word is examined through authentic language acts.

Finally, anglicisms used in the Polish LGBTQ+-related discourse call for a reconsideration of the much-quoted motive for borrowing foreign material, i.e., the need to fill lexical gaps in one's native tongue. While the recipient language speakers are assumed to borrow foreign material to express a new (to them) foreign concept, as in the case of e.g., Ayatollah, Halloween, and sushi in several European languages, LGBTQ+ anglicisms seem to express or re-name concepts that have been known, yet unexpressed or labelled with negatively connoted native words. English-sourced loans help communicate group membership, serve to construct and express gender identity, and mirror changes in societal consciousness.

\section{Acknowledgements}

I would like to express gratitude to my students, Joanna Bojarska and Rafał Piekarz, and to my colleagues and friends, Robert Kusek, Wojciech Szymański, and Tomasz Sikora, for their invaluable help in directing me to data sources and publications, and finding language data and informants for this project. I would like to thank Mirosław Bańko for sharing with me his lexicographic expertise. Any inconsistencies or shortcomings remain my own. 
Appendix: LGBTQ+-related anglicisms found in Polish texts ${ }^{11}$

\section{English-sourced loanwords (adapted and unadapted)}

agender 'one who does not identify as a particular gender', AIDS/eids, ally 'a heterosexual supporter of the LGBTQ+ community', bareback/bb 'to have sex without using a condom', $B D S M$ 'an umbrella term for various types of erotic play', bears 'a gay man with specific traits, e.g., a hairy body, large built', *bicurious 'one who considers experimenting with bisexuality', biczlbycz 'various interpretations' ( $<$ Eng. bitch), bigenderowy 'of a person who identifies as both male and female' (< Eng. bigender), blowjob 'type of sexual activity', bondage 'type of erotic play', boner 'an erect penis', bottom 'the passive partner in anal sex', Broadway/Brodtej 'a meeting place for male homosexuals' [obsolete; absent from Eng. gay slang], *bugchasing 'sexual activity aimed at contracting HIV', butch/buczka 'a person with male-like appearance' ( $<$ Eng. butch), callboy 'a male prostitute', *chaser/szaser 'a gay man attracted to a particular type of men', chemsex 'having sex while being high on drugs', cisgender 'a person whose personal identity and gender correspond with their birth sex', cishet 'cisgender + heterosexual', cisseksizm 'discrimination against transgender people' (< Eng. cissexism), cisseksualny 'cisgender' ( $<$ Eng. cissexual), closet/sklozetowany 'the status of a homosexual who is yet to declare their homosexuality', *cock, cock ring, color code 'colour code used to indicate preferred sexual fetishes', coming out, crossdressing 'wearing clothes and acting as a member of the opposite sex', crossdresser/crossdreserka, cruising bar [see: kruzing below], cybersex/cyberek, daddy 'various interpretations', darkroom 'a darkened room in a gay club where sexual activity takes place', dick, dildo, drag/dragowy 'the practice of dressing up as the opposite sex; also refers to mental or emotional state of being', drag king 'a lesbian who dresses as a man', drag queen 'a gay man who dresses as a woman', drag show, drama queen 'a person whose emotional response tends to be exaggerated', dress code, *dyke 'a lesbian', *fag hag 'the female friend of a gay man', *faggot/fag 'a gay man' [usu. derog.], fakanielfaknięcie (< Eng. fuck), femka 'passive and more feminine partner in a lesbian couple' (< Eng. fem/femme), FFS 'facial feminization surgery', fisting 'type of sexual practice' ( $<$ Eng. fist, fistfuck), fluidlfluidity 'of a heterosexual person who can be attracted to the same sex', *friend of Dorothy 'a gay man', FTM/F2M 'female to male; a person who has undergone female to male sexual reassignment surgery', gang/gang bang 'group sex', gay/gej, gay

11 Expressions marked as rare or niche by the informants are preceded with an asterisk $(*)$. English etymons are provided where the loan differs formally from its model. 
club, gay party, gaydarlgejdar 'gay + radar; an instinct that enables homosexual people to recognise other gay people', gay-friendly, gej-czat (< Eng. gay chat), gender, gender mainstreaming 'a policy aiming at equal treatment of man and women', gender studies, genderbending 'deliberately disrupting the bipolar gender system', *genderfuck 'a male wearing woman clothing and beard at the same time, deliberately disrupting the bipolar gender system', glory hole 'a hole cut in the partition between stalls in a men's room for oral or anal intercourse', * grayasexual/grey-aseksualny 'a person who feels sexual attraction infrequently or has no desire to act on it', GRS 'gender reassignment surgery', heteroseksizm 'prejudice against homosexuals' (< Eng. heterosexism), HIVIhif, jack-off 'masturbate', joystick 'an erect penis', kamp 'various interpretations' [see, e.g., Baker 2002: 93] (<Eng. camp), kesz/\$ [used in gay chats] (< Eng. cash), kruzing 'looking for casual sex' ( $<$ Eng. cruising), leather 'leather clothing; leatherman', LGBT, LGBTA, LGBTAF, LGBTAI, LGBTQ(+), LGBTQA, LGBTQQIAAP2+ 'lesbian, gay, bisexual, transgender, queer, questioning, intersex, asexual, agender, pansexual, two-spirited', $M 2 M$ 'man to man; a female (who never felt female) who has undergone female to male sexual reassignment surgery', master 'a person who plays the dominant role in BDSM sexual roleplay', MSM 'man searching man' [used in ads.], $M T F / M 2 F$ 'male to female; a transsexual or transgendered person', naked party, no pic(s) no chat 'no pictures, no chat' [used in chats], outing 'revealing an LGBT person's sexual identity without their consent' ( $<$ Eng. outing; to out someone), pink money 'the money spent by the LGBT community', pride 'the belief that gay is good', queen 'a gay man', queer/queerowy/queerowośćlktir/ktirowy/ktirować 'other than heteronormative; various interpretations', queer studies, rimming 'a type of sexual practice', *rise queen 'a gay man attracted to Asian men', (sex-)chat, skate 'a gay man dressed in the fashion of a skateboarder' ( $<$ Eng. skater), slave 'a person who is sexually submissive', sling 'a hammock-like device used in sex', $S M$ 'sadism, masochism', sneaker/sniker 'a gay man wearing sports shoes', sneaker party, sniker seks 'a type of sexual practice' (< Eng. sneaker sex), soksy (< Eng. socks), spanking 'type of sexual practice', SRS 'sex reassignment surgery', *TERF/terf 'trans-exclusionary radical feminist', *threesome 'sex between three people', tomboy 'a girl who acts or dresses in a boyish way', top 'the active partner in anal sex', transgender/transgenderowy 'of a person who challenges stereotypically gender boundaries', tribe 'self-identification of gay man, e.g., bear, daddy, leather, otter', *truscum 'a transgender person who believes that one needs to experience body dysphoria to be considered transgender', twink 'a young, boyish gay man', *uncut 'not circumcised', underwear party, *vanilla sex 'conventional sex; used in contrast to SM sex', wyautować/wyautowany/wyautowanie 'to reveal an LGBT person's sexual identity without their consent' (< Eng. outing; to out someone) 


\section{English-sourced loan translations, loan renditions and loanblends}

artysta drag/drag artysta (< Eng. drag artist), bar gejowski (< Eng. gay bar), bezpieczny seks (< Eng. safe sex), Bóg stworzyt Adama $i$ Ewę, nie Adama $i$ Steve'a (< Eng. God made Adam and Eve, not Adam and Steve), Bóg stworzyt Adama i Ewę, nie Madame i Ewę (< Eng. God made Adam and Eve, not Madam and Eve), ciskobieta (< Eng.cis(gender)woman), cismężczyzna (< Eng. cis(gender) man), cisnorma (< Eng. cisnorm), cisnormatywnośćlcisnormatywny (< Eng. cisnormative), cisptciowy/cisptciowość (< Eng. cissexual), czat gejowski (< Eng. gay chat), drag przedstawienie (< Eng. drag show), duma gejowskallesbijska (< Eng. gay/lesbian pride), duma LGBT (< Eng. LGBT pride), dziura/otwór chwaty/chwalebna dziura 'a hole cut in the partition between stalls in a men's room for oral or anal intercourse' (< Eng. glory hole), emancypacja homoseksualna (< Eng. homosexual emancipation), fenotyp płciowy (< Eng. sexual phenotype), flaga dumy (< Eng. pride flag), flaga gejowska (< Eng. gay flag), flaga lesbijska (< Eng. lesbian flag), flaga tęczowa (< Eng. rainbow flag), gejowska ikona (< Eng. gay icon), gej randka $(<$ Eng. gay date), HIV pozytywny (< Eng. HIV-positive), interptciowy/interptciowość ( $<$ Eng. intersex/intersexuality), język lawendowy ( $<$ Eng. lavender language), kino queer(owe) (< Eng. queer cinema), klub gejowski (< Eng. gay club), klub miśków/niedźwiedzi (< Eng. gay bear club), kod flagowy 'colour handkerchiefs worn to indicate preferred sexual fetishes' (< Eng. hanky code), kryptogej/kryptuch (< Eng. crypto-gay), kultura drag kings (< Eng. drag kings culture), kultura drag queen (< Eng. drag queen culture), kultura gejowska (< Eng. gay culture), kultura LGBT (< Eng. LGBT culture), lawendowe językoznawstwo (< Eng. lavender linguistics), matzeństwo homoseksualne ( $<$ Eng. homosexual marriage/couple), matżeństwo jednoptciowe ( $<$ Eng. samesex marriage), matżeństwo różnoptciowe ( $<$ Eng. different-sex marriage), marsz dumy (< Eng. pride parade), mniejszość seksualna (< Eng. sexual minority), niewidzialność lesbijek ( $<$ Eng. lesbian invisibility), odmieńczy $(<$ Eng. queer), para homoseksualna (< Eng. homosexual couple), para jednoptciowa $(<$ Eng. same-sex couple), parada/marsz równości (< Eng. pride parade), pleć mózgu $(<$ Eng. brain sex), pteć prawna (< Eng. legal sex), płeć psychiczna $(<$ Eng. psychic sex), plynny płciowo/plynność ptciowa 'of a person whose gender identity varies over time' ( $<$ Eng. genderfluid/gender fluidity), polityka tożsamościowa (< Eng. identity policy), polowanie na robala 'sexual activity aimed at contracting HIV' (< Eng. bugchasing), prawa gejowskie (< Eng. gay rights), prawa mniejszości seksualnych (< Eng. sexual minority rights), przyjaciel Doroty 'a gay man' (< Eng. a friend of Dorothy), równość matżeńska (< Eng. marriage equality), równość ptci (< Eng. sex equality), różowa flaga 'a symbol of the LGBT community' (< Eng. pink flag), różowe pieniadze 'the money spent by the LGBT 
community' (< Eng. pink money), różnorodność seksualna (< Eng. sexual diversity), ruch gejowski (< Eng. gay movement), skórzak (< Eng. leatherman), społeczność gejowska $i$ lesbijska (< Eng. gay and lesbian community), społeczność LGBT (< Eng. LGBT community), stres mniejszościowy (< Eng. minority stress), studia gender ( $<$ Eng. gender studies), studia queer(owe) $(<$ Eng. queer studies), szara aseksualność 'of a person who feels sexual attraction infrequently or has no desire to act on it' (< Eng. gray asexuality), szminkowa lesbijka 'a female homosexual who exhibits a lot of feminine gender attributes' (< Eng. lipstick lesbian), tęczowa rodzina 'same-sex or LGBT family' (< Eng. rainbow family), teoria queer (< Eng. queer theory), terapia konwersyjna ( $<$ Eng. conversion therapy), terapia reparatywna (< Eng. reparative therapy), tożsamość gejowska (< Eng. gay identity), tożsamość LGBT (< Eng. LGBT identity), tożsamość plciowa (< Eng. gender/sexual identity), tożsamość seksualna (< Eng. sexual identity), transkobieta (< Eng. transwoman), transmężczyzna (< Eng. transman), transpłciowośćltranspłciowy $(<$ Eng. transgender), trzecia pteć ( $<$ Eng. third gender/sex), wychodzić z szafy ( $<$ Eng. to come of the closet), występ dragowy (< Eng. drag performance), zwiazek homoseksualny ( $<$ Eng. homosexual relationship), zwiazek jednoptciowy $(<$ Eng. same-sex relationship), zwiazek partnerski (< Eng. partner relationship)

\section{English-sourced semantic loans}

aktywista 'a person who fights for gay rights' ( $<$ Eng. activist), aktywny/aktyw/a 'the active partner in anal sex' ( $<$ Eng. active), as 'an asexual person' $(<$ Eng. ace), ciemnia 'a darkened room in a gay club where sexual activity takes place' (< Eng. darkroom), czajniczek 'a gay man with one hand on the hip and the other held at shoulder height' ( $<$ Eng. teapot), fioletowy 'a symbol for gay pride' ( $<$ Eng. purple), fiotki 'a symbol for the lesbian community' $(<$ Eng. violet), hiacynt 'a gay person' ( $<$ Eng. hyacinth), inkluzywny 'friendly towards the LGBT community' ( $<$ Eng. inclusive), jednorożec 'a symbol for camp aesthetics' ( $<$ Eng. unicorn), lawendowy 'relating to the LGBT community' $(<$ Eng. lavender), misiek/miś/niedźwiedź 'a gay man with specific traits, e.g., a hairy body, large built' (< Eng. bear), [seksualna] mniejszość (< Eng. [sexual] minority), niebinarny 'a person who does not identify as exclusively male or female' ( $<$ Eng. nonbinary), niewolnik 'a person who is sexually submissive' $(<$ Eng. slave), odmienieclodmienność (< Eng. queer), partner [seksualny] ( $<$ Eng. partner), pasywny/pasyw/p 'the passive partner in anal sex' $(<$ Eng. passive), plynnośćlptynny 'of a heterosexual person who can be attracted to the same sex' ( $<$ Eng. fluidity/fluid), pozytywny 'infected with HIV' $(<$ Eng. positive), robal 'AIDS; HIV' (< Eng. bug), rodzina 'the gay and lesbian community' (< Eng. family), równośćlrównościowy 'equal regardless of one's sexuality 
or gender' (< Eng. equality), sojusznik/sojuszniczka 'a heterosexual person who supports the LGBT community' (< Eng. ally), szafa 'the status of a homosexual who is yet to declare their sexuality' ( $<$ Eng. closet), tęczaltęczowy 'a symbol for the LGBT community celebrating gay diversity and pride' ( $<$ Eng. rainbow), tranzycja (ptciowa) 'a change from one gender role to another involving changes in the way one looks and behaves' ( $<$ Eng. (gender) transition), ujawnienie sie 'openly declaring and accepting one's sexuality' (< Eng. coming out (of the closet)), uniwersalny 'both active and passive in anal sex' ( $<$ Eng. universal)

\section{REFERENCES}

\section{PRIMARY DATA ${ }^{12}$}

Bear news pl. https://bear-news-pl.blogspot.com.

Biedroń, Robert. 2007. Tęczowy elementarz: czyli (prawie) wszystko, co chcielibyście wiedzieć o gejach i lesbijkach. AdPublik.

Domeq - Krakowskie Centrum Równości. https://www.facebook.com/domeq.krk.

Dubrowska, Magdalena. 2010. Słownik LGBTQ. Żebyście wiedzieli, o czym mówią w branży. Gazeta Wyborcza. 17.07.2010. https://warszawa.wyborcza.pl/warszawa/1,95190,8148024, Slownik_LGBTQ_Zebyscie_wiedzieli_o_czym_mowia_w.html.

Encyklopedia LGBT. https://www.encyklopedia.edu.pl. (sel. art.)

Homiki.pl. https://www.homiki.pl. (sel. art.)

InterAlia: A Journal of Queer Studies. https://interalia.queerstudies.pl. (sel. art.)

JEJPerfekcyjność.pl. https://jejperfekcyjnosc.p1/2018/01/orientacja-seksualna-i-tozsamosc-plciowaslowniczek-nie-tylko-dla-poczatkujacych.

Kochanowski, Jacek, Marta Abramowicz \& Robert Biedroń (eds.). 2010. QUEER studies: Podręcznik kursu. Kampania Przeciw Homofobii. (sel. art.)

Omyliński, Janusz. 2012. Kod seks-czatów i slang gejów. Tajemny język branży. https://natemat.pl/4759,kod-seks-czatow-i-slang-gejow-tajemny-jezyk-branzy.

Kościańska, Agnieszka. Karolina Morawska, Jędrzej Burszta \& Tomasz Basiuk (eds.). 2019. Różowy język. https://interalia.queerstudies.pl/wp-content/uploads /2019/10/InterAlia_ 14_2019.pdf. (sel. art.)

Kita, Małgorzata. 2014. Coming out. Nowy gatunek na polskiej mapie genologicznej, zdarzenie komunikacyjne, wydarzenie medialne. In Małgorzata Karwatowska, Robert Litwiński, Adam Siwiec \& Beata Jarosz (eds.), O ptci, ciele i seksualności w języku i mediach, Wydawnictwo UMCS. 321-341.

Kobieta NIE/HETEROnormatywna. http://www.knh.vxm.pl. (sel. art.)

Kobiety Kobietom. https://kobiety-kobietom.com (sel. art.)

12 All websites listed in this section were accessed between February 14 and July 14, 2020. The abbreviation "(sel. art.)" stands for "selected articles". 
Majka, Rafał. 2015. Poza "bezpieczniejszym seksem" - bareback i fetyszyzacja seksu bez zabezpieczenia. InterAlia: A Journal of Queer Studies 10/2015. 195-216. https://interalia.queerstudies.pl/wp-content/uploads/10_2015/majka.pdf.

Miłość nie wyklucza. https://www.facebook.com/Miloscniewyklucza/, https://twitter.com/milosc_.

Mistycyzm Popkulturowy. https://mistycyzmpopkulturowy.blogspot.com. (sel. art.)

Niepytalska-Osiecka, Agnieszka. 2016. O najnowszych znaczeniach czasowników wyautować i wyautować się. Poradnik Językowy 2016(6). 77-84.

Queer. Portal ludzi LGBT. https://queer.pl. (sel. art.)

Replika. https://replika-online.pl. (sel. art.)

Równość.info. https://rownosc.info/dictionary.

Ruch LGBT. https://ruchlgbt.pl. (sel. art.)

Sistrum. Przestrzeń kultury lesbijskiej. http://sistrum.org.pl. (sel. art.)

Symbole LGBT. https://pl.wikipedia.org/wiki/Symbole_LGBT.

Świder, Magda \& Mikołaj Winiewski. 2017. Sytuacja społeczna osób LGBTA w Polsce. Raport za lata 2015-2016. KPH. https://kph.org.pl/wp-content/uploads/2017/11/Sytuacjaspoleczna-osob-LGBTA-w-Polsce.pdf.

Tęczowy jednorożec. https://twitter.com/holy_holiness.

TęczowyS. https://twitter.com/TeczowyS.

Tęczuj. https://www.facebook.com/teczuj.

Trzyczęściowy garnitur. https://trzyczesciowygarnitur.blogspot.com.

Warkocki, Błażej. 2013. Różowy język. Literatura i polityka kultury na początku wieku. Wydawnictwo Krytyka Polityczna.

Warkocki, Błażej. 2014. Trzy fale emancypacji homoseksualnej w Polsce. Porównania 15. 121-132.

Wiara i Tęcza. https://www.facebook.com/WiaraiTecza

Witkowski, Michał. 2014. Lubiewo. Korporacja Ha!art.

\section{DICTIONARIES}

$\mathrm{AHD}=$ The American Heritage Dictionary of the English Language. https://www.ahdictionary.com.

Baker, Paul. 2002. Fantabulosa. A Dictionary of Polari and Gay Slang. Continuum.

$\mathrm{ED}=$ Online Etymology Dictionary. https://www.etymonline.com.

$\mathrm{FD}=$ The Free Dictionary. https://www.thefreedictionary.com.

Rodríguez González, Félix. 2008b. Diccionario gay-lésbico. Gredos.

Rodríguez González, Félix \& Antonio Lillo Buades. 1997. Nuevo diccionario de anglicismos. Gredos.

Słownik warszawski = Jan Karłowicz, Adam Kryński, Władysław Niedźwiedzki (eds.). 1900-1927. Stownik języka polskiego. Nakładem prenumeratorów.

SZA = Elżbieta Mańczak-Wohlfeld (ed.). 2010. Stownik zapożyczeń angielskich $w$ polszczyźnie. PWN.

WSWO = Mirosław Bańko (ed.). 2003. Wielki słownik wyrazów obcych. PWN. 


\section{ONLINE GLOSSARIES}

French gay slang words. https://www.talkinfrench.com/french-gay-slang.

French LGBTQ+ vocabulary. https://www.frenchtoday.com/blog/french-vocabulary/french-lgbtqvocabulary.

GLTB Slang Dictionary. http://andrejkoymasky.com/lou/dic/dic00.html.

JEJPerfekcyjność.pl. https://jejperfekcyjnosc.p1/2018/01/orientacja-seksualna-i-tozsamosc-plciowaslowniczek-nie-tylko-dla-poczatkujacych.

Pink News. https://www.pinknews.co.uk/2017/11/27/the-ultimate-lgbt-glossary-all-yourquestions-answered.

Queer undefined, a crowdsourced lgbtq+ dictionary. https://www.queerundefined.com.

Równość.info. https://rownosc.info/dictionary.

Słownik LGBTQ. https://warszawa.wyborcza.pl/warszawa/1,95190,8148024,Slownik_LGBTQ __Zebyscie_wiedzieli_o_czym_mowia_w.html.

\section{SECONDARY SOURCES}

Baker, Paul. 2019. Fabulosa! The story of Polari, Britain's secret gay language. Reaktion Books.

Backus, Ad. 2014. A usage-based approach to borrowability. In Eline Zenner \& Gitte Kristiansen (eds.), New perspectives on lexical borrowing: Onomasiological, methodological and phraseological innovations, De Gruyter Mouton. 19-39. DOI: https://doi.org/10.1515/9781614514305.19

Bieńko, Mariola. 2019. "Pedał" i "lesba" jako społeczne pojęcia życia codziennego. Heteroseksualne uprzedzenia językowe dotyczące gejów i lesbijek. InterAlia 14/2019. 86-102.

Cierpich, Agnieszka. 2019. Zapożyczenia angielskie w polszczyźnie korporacyjnej. Wydawnictwo Naukowe Akademii Ignatianum.

Cox, Leslie \& Richard Fay. 1994. Gayspeak, the linguistic fringe: Bona Polari, camp, queerspeak and beyond. In Stephen Whittle (ed.), The margins of the city. Gay men's urban lives, Arena. 103-127.

Crespo-Fernández, Eliecer \& Carmen Luján-García. 2017. Anglicisms and word axiology in homosexual language. Revista Española de Lingüística Aplicada 30(1). 74-103. DOI: $10.1075 /$ resla.30.1.04cre

Curzan, Anne. 2014. Fixing English: Prescriptivism and language history. Cambridge University Press.

Divita, David \& William Curtis. 2019. The life of a loanword: A case study of le coming out in the French magazine Têtu (1995-2015). Ampersand 6. 100053. DOI: $10.1016 /$ j.amper.2019.100053

Dyszak, Andrzej S. 2012a. O socjolekcie gejów (na podstawie powieści Michała Witkowskiego pt. Lubiewo. In Małgorzata Karwatowska \& Jolanta Szpyra-Kozłowska (eds.), Oblicza płci. Język - Kultura - Edukacja, Wydawnictwo UMCS. 29-42.

Dyszak, Andrzej S. 2012b. Nazwy mężczyzn homoseksualnych we współczesnym języku polskim. Studia Językoznawcze 11. 55-80.

Dyszak, Andrzej S. 2015. O zapisanym słownictwie mniejszości seksualnych. Etnolingwistyka 27. 201-220. DOI: 10.17951/et.2015.27.201

Dyszak, Andrzej S. 2016. The lexis of Polish sexual minorities slang. Philology 1(5). 59-67. 
Fisiak, Jacek. 1961. Zapożyczenia angielskie w języku polskim: Analiza interferencji leksykalnej. Ph.D. dissertation, Łódź University.

Fisiak, Jacek. 1970. The semantics of English loanwords in Polish. Studia Anglica Posnaniensia 2. 41-49.

Górnicz, Mariusz. 2019. Wewnątrzjęzykowe uwarunkowania zapożyczeń technolektalnych w język polskim. Wydawnictwo Naukowe IKSiI UW.

Grabias, Stanisław. 1997. Język $w$ zachowaniach społecznych. Wydawnictwo Uniwersytetu Marii Curie-Skłodowskiej.

Haggerty, George. 2013. Encyclopedia of gay histories and cultures. Routledge.

Haugen, Einar. 1950. The analysis of linguistic borrowing. Language 26(2). 210-231. DOI: $10.2307 / 410058$

Kita, Małgorzata. 2016. Coming out $w$ polskiej przestrzeni dyskursywnej. Wydawnictwo Uniwersytetu Śląskiego.

Koneczna, Halina. 1936-1937. Wyrazy angielskie w języku polskim. Poradnik Językowy 9. 161-170.

Krzyszpień, Jerzy. 2010. Język i emancypacja LGBT: Uwagi praktyczne. In Jacek Kochanowski, Marta Abramowicz \& Robert Biedroń (eds.), QUEER studies: Podręcznik kursu, Kampania Przeciw Homofobii. 139-146.

Leap, William L. \& Tom Boellstorff (eds.). 2004. Speaking in queer tongues. Globalization and gay language. University of Illinois Press.

Łydka, Katarzyna. 2019. Proces thumaczenia powieściowego języka gejów na język polski na przykładzie powieści The Line of Beauty Alana Hollinhursta. Zeszyty Naukowe Towarzystwa Doktorantów UJ, Nauki Humanistyczne 24(1). 127-145. DOI: 10.26361/ZNTDH.10.2019.24.08

Mańczak-Wohlfeld, Elżbieta. 1988a. Anglicyzmy w Słowniku warszawskim. Język Polski 68(1) 24-29.

Mańczak-Wohlfeld, Elżbieta. 1988b. Semantic fields of English loanwords in modern Polish. Kwartalnik Neofilologiczny 35. 271-284.

Mańczak-Wohlfeld, Elżbieta. 1992. Analiza dekompozycyjna zapożyczeń angielskich $w$ języku polskim. Uniwersytet Jagielloński.

Mańczak-Wohlfeld, Elżbieta. 1995. Tendencje rozwojowe wspótczesnych zapożyczeń angielskich w języku polskim. Universitas.

Mańczak-Wohlfeld, Elżbieta. 2010. Stownik zapożyczeń angielskich w polszczyźnie. PWN.

Miodunka, Władysław. 1980. Teoria pól językowych. Społeczne i indywidualne ich uwarunkowania. Wydawnictwo Uniwersytetu Jagiellońskiego.

Nowak, Tomasz Łukasz. 2016. Gdzie jest gej? O (nazwach) przestrzeni w pierwszych polskich pismach gejowskich. Dziennikarstwo $i$ Media 7. 173-185. DOI: 10.19195/20828322.7.13

Nowak, Tomasz Łukasz. 2017. O kulturowych relacjach między wybranymi nazwami geja. Etnolingwistyka 29. 245-255.

Nowak, Tomasz Lukasz. 2018. Selected terms for gay men in contemporary Polish: Cultural connotations. Ethnolinguistic 29. 265-274. DOI: 10.17951/et.2017.29.245

Nowak, Tomasz Łukasz. 2019. Przez język ukrycia po słowo na "g”. Kim są bohaterowie czasów queer before gay? Poznańskie Studia Slawistyczne 16. 193-208. DOI: $10.14746 /$ pss.2019.16.11

Nowak, Tomasz Łukasz. 2020. Język ukrycia. Zapisany socjolekt gejów. Universitas. 
Omyliński, Janusz. 2012. Kod seks-czatów i slang gejów. Tajemny język branży. https://natemat.pl/4759,kod-seks-czatow-i-slang-gejow-tajemny-jezyk-branzy.

Onysko, Alexander \& Esme Winter-Froemel. 2011. Necessary loans - luxury loans? Exploring the pragmatic dimension of borrowing. Journal of Pragmatics 43(6). 1550-1567. DOI: 10.1016/j.pragma.2010.12.004

Otwinowska-Kasztelaniec, Agnieszka. 2000. A study of the lexico-semantic and grammatical influence of English on the Polish of the younger generation of Poles. Dialog.

Provencher, Denis M. 2007. Queer French: Globalization, language, and sexual citizenship in France. Ashgate Publishing.

Rejter, Artur. 2013. Pteć-język - kultura. Wydawnictwo Uniwersytetu Śląskiego.

Rodríguez González, Félix. 2008a. Anglicisms in Spanish male homosexual terminology. In Roswitha Fischer \& Hanna Pułaczewska (eds.), Anglicisms in Europe. Linguistic diversity in a global context, Cambridge Scholars Publishing. 247-271.

Rodzoch-Malek, Jagoda. 2012. W jaki sposób mówi się w polszczyźnie o homoseksualizmie i osobach homoseksualnych? Analiza leksyki na podstawie danych leksykograficznych i tekstowych. Ph.D. dissertation, Uniwersytet Warszawski. http://depotuw.ceon.pl/handle/item/204

Scheller-Boltz, Dennis. 2017. LGBT? LGBTQ+? LGBTTQQFAGPBDSM? Or just: QUEER! Critical remarks on an acronym in Slavonic and non-Slavonic languages. In Peter Handler, Klaus Kaindl \& Holger Wochele (eds.), Ceci n'est pas une festschrift. Texte zur Angewandten und Romanistischen Sprachwissenschaft für Martin Stegu, Logos. 279-291.

Thomason, Sarah G. \& Terrence Kaufman. 1988. Language contact, creolization, and genetic linguistics. University of California Press. DOI: 10.1525/9780520912793

Witalisz, Alicja. 2007. Anglosemantyzmy w języku polskim - ze słownikiem. Tertium.

Witalisz, Alicja. 2015. English loan translations in Polish: Word-formation patterns, lexicalization, idiomaticity and institutionalization. Peter Lang.

Witalisz, Alicja. 2016. Przewodnik po anglicyzmach w języku polskim. TMJP PAN.

Wilkoń, Aleksander. 2000. Typologia odmian językowych współczesnej polszczyzny (2nd edn.). Wydawnictwo Uniwersytetu Śląskiego.

Zabawa, Marcin. 2012. English lexical and semantic loans in informal spoken Polish. Wydawnictwo Uniwersytetu Śląskiego.

Zabawa, Marcin. 2017. English semantic loans, loan translations and loan renditions in informal Polish of computer users. Wydawnictwo Uniwersytetu Śląskiego.

Zabłocki, Krzysztof. 2019. Luj przyjacielem Dorotki? Meandryczne metarefleksje o tęczowym języku z filologiczno-komparatystycznym przegięciem. InterAlia 14. 121-135. 